\title{
New Monasticism: An Answer to the Contemporary Challenges of Catholic Monasticism?
}

\author{
Stefania Palmisano ${ }^{1, *}$ and Marcin Jewdokimow ${ }^{2}$ (1) \\ 1 The Department of Cultures, Politics and Society, University of Turin, 10153 Torino, Italy \\ 2 Faculty of Humanities, Cardinal Stefan Wyszyński University in Warsaw, 01-815 Warszawa, Poland \\ * Correspondence: stefania.palmisano@unito.it
}

Received: 4 June 2019; Accepted: 26 June 2019; Published: 28 June 2019

\begin{abstract}
New Monasticism has been interpreted by its protagonists as an answer to the challenges of the future of Christian monasticism. New Monastic Communities can be defined as groups of people (at least some of whom have taken religious vows) living together permanently and possessing two main characteristics: (1) born in the wake of Vatican Council II, they are renewing monastic life by emphasising the most innovative and disruptive aspects they can find in the Council's theology; and (2) they do not belong to pre-existing orders or congregations-although they freely adapt their Rules of Life. New Monastic Communities developed and multiplied in the decades during which, in Western European countries and North America, there was a significant drop in the number of priests, brothers and sisters. Based on our empirical research in a new monastic community-the Fraternity of Jerusalem (a foundation in Poland) - we addressed the following: Why are New Monastic Communities thriving? Are they really counteracting the decline of monasticism? What characteristics distinguish them from traditional communities? We will show how they renew monastic life by emphasising and radicalising the most innovative and disruptive theological aspects identified in Vatican Council II.
\end{abstract}

Keywords: New Monastic Communities; Vatican Council II; monasticism

\section{Introduction}

Looking at the phenomenon of the Catholic religious life from the perspective of the last 300 years, one notices a sine wave tendency: after its collapse in the eighteenth century, there was a spectacular development in the nineteenth and twentieth centuries which stopped circa the mid-1960s when a reduction in the number of religious sisters, brothers and priests began. The eighteenth-century collapse was strictly related to the Enlightenment: its political consequences and the regional contexts in which it proceeded triggered the politics of dissolution of the monasteries and religious orders-a deliberate, state-driven politics of closure and appropriation of their fortunes. Hostie (1983) showed that between 1770 and 1850, the decrease may be counted in the hundreds of thousands: while in 1770 there were almost 300,000 members of male religious orders, by 1850 there were 200,000 fewer (Hostie 1983 after Finke and Wittberg 2000, p. 159). In Europe, the number of Franciscans dropped from 133,000 in 1815 to 39,000 in 1850; Dominicans decreased from 30,000-40,000 in 1780 to 5000 in 1844; in France, the number of Benedictine monasteries decreased from 2000 in 1789 to 20 in 1815 (Wittberg 1994, p. 38). In Poland, the general number of male monasteries dropped from 990 in 1772 to 188 in 1914 and the number of religious priests and brothers from 14,540 to 2252 in the same period (Derwich 2012). The slow increase began in the years after 1850, but these were new groups, founded after 1800 and not in previously established orders, who attracted new members (Finke and Wittberg 2000). In the nineteenth century (between 1800 and 1880), 400 new female religious communities were established in France, with 200,000 sisters, while in Ireland, their number increased rapidly from 1800 to 8000 
(between 1800 and 1900), and in America, from more than 1300 to more than 40,000 (between 1850 and 1900) (Finke and Wittberg 2000, p. 160). Growth continued up to the middle of the 1960s, when the present "crisis" began. For instance, between 1974 and 2015, there was a general drop in the number of nuns from over 980,000 to 670,000 (-32 per cent); in the number of religious brothers from 70,500 to 54,000 ( -23 per cent); and religious priests by 9 percent, from almost 147,000 to 134,000 . At the same time, however, Catholic religious orders developed and grew in Africa, Asia and South America. Hence, even though the drop is clear in terms of quantity, it is not the general trend (Jewdokimow 2018).

In sociological terms, the reasons for the "crisis" in Europe and North America is usually explained by pointing to: (1) discrepancies between the form of religious life and the changing attitudes and needs of young Catholics (Greeley 1972); (2) social changes, which-leading to the secularisation of societies-reduced the attractiveness of the religious life, and at the same time created many new life opportunities, including professional ones, especially in economically developed countries, in particular, for women (Ebaugh 1977, 1993; Ebaugh et al. 1996; Finke and Stark 2000); and (3) reforms initiated by the Second Vatican Council (Dilanni 1993; Finke 1997; Finke and Stark 1992; Wittberg 1994). The significance of the Council is interpreted in sociological texts above all in the context of reducing the unique value of religious life in the eyes of both secular and religious people. The basis for this claim is derived from three post-conciliar documents: Lumen Gentium, Gaudium et Spes and Perfectae Caritatis. For example, Finke and Stark (2000) indicate that, as a result of these records, all Christians (not only consecrated persons) were defined as seeking sanctity (although this is actually a reminder of biblical records and it is a significant one), and religious life from now on should be directed towards the world, and not away from it by seeking enclosure. These losses-as these changes in the spirit of the theory of rational choice are defined-were not compensated by either a reduction in the cost of this demanding lifestyle or reward for them in the secular sphere (there was no increase in prestige, nor partial decline) (Finke and Stark 2000; Wittberg 1994). There are also indications of organisational changes related to the Council's provisions: limitation of collective activities for the growth of individual activities, which is treated as a factor that diminishes the sustainability of these communities (Finke and Stark 2000), as well as identity crises of religious priests (Sammon 2001). ${ }^{1}$

While discussing the challenges of monasticism today, one cannot omit these general tendencies and social changes. However, the weakness of these data is related to its institutional provenance. It should be emphasized that the above analysis refers to institutionally recognised and approved forms of consecrated life, which, according to the data, are in crisis because of the drop in the number of their members. However, does it indicate that monasticism and Catholic religious life in general are in crisis? As in the nineteenth century, today we observe the emergence of new religious forms, such as individual types of consecrated life, secular institutes, New Monastic Communities or other hybrid forms which absorb elements of traditions in religious life, attracting sincere individuals, yet they evade clear categorisation and institutional recognition due to which it is almost impossible to present their development quantitatively. We claim that focusing on these emerging forms may help us to understand how Catholic religious life in general, and monasticism in particular, seek to address both the "crisis" and the challenges of the contemporary world. Hence, even though we observe the massive drop in Catholic religious orders it is perhaps a mistake to interpret it as a general crisis of consecrated life. Rather, what we see is a stage of transformation. That transformation is triggered by both external and internal factors. External factors were reviewed above in the form of sociological hypothesis. Internal factors are related to institutional changes which affect all institutions. Analysing the history of

1 It should be emphasised that some of the theological interpretations of the Council with regard to its provisions and consequences also emphasise its negative influence on the condition of religious life. In 2005, Benedict XVI spoke about two hermeneutics (discontinuities and reforms) of the Second Vatican Council and constant discussion on this background. In addition, the reforms of religious life did not conclude with the Second Vatican Council, they are ongoing-the latest publication in this regard is New wine in new wineskins. The consecrated life from the Second Vatican Council and its ongoing challenges since Vatican II. Guidelines. (the publication is a result of the 2014 meeting of the Congregation for Institutes of Consecrated Life (2017) and Societies of Apostolic Life). 
religious orders, Roger Finke and Patricia Wittberg conclude that these religious institutions undergo "the periodic cycles of revival, decline, and even extinction [... ] and follow a life cycle that resembles that of a Protestant sect. The life of the movement begins in a high state of tension with the surrounding culture and seeks to make changes by restoring an old tradition or introducing a new one. Over time, however, the religious order frequently accommodates to the surrounding culture and the religious fervour of the founders becomes lost in highly routinized rituals" (Finke and Wittberg 2000, p. 166).

From the spectrum of new forms of consecrated life, within this article we focus on New Monastic Communities. $^{2}$ We claim that studying these entities allows us to address many relevant contemporary questions concerning general issues in religion, such as: How does religion transform itself in secular societies? How do religious institutions operate in a secular social context? How does culture intercept elements of the religious life and employ it for secular goals? This article is devoted to more limited, yet also vital questions. Based on our empirical research within one new monastic community - the Fraternity of Jerusalem (Poland)—we address the following questions: Why are New Monastic Communities thriving? Are they really counteracting the decline of monasticism? What characteristics distinguish them from traditional communities? More precisely, what are the breaking-off and continuity points? Do NMCs simply re-adjust traditional monasticism or do they transform it radically to the extent of (re)inventing it? Hence, we address here the questions of the future and challenges to Catholic monasticism.

\subsection{Defining NMCS}

New Monasticism has been interpreted by its protagonists as an answer to challenges of the future of Christian monasticism. New Monastic Communities can be defined as groups of people (at least some of whom have taken religious vows) living together permanently and possessing two main characteristics: (1) born in the wake of Vatican Council II, they are renewing monastic life by emphasising the most innovative and disruptive aspects they can deduct from the Council's theology; (2) they do not belong to pre-existing orders or congregations-although they freely adapt their Rules of Life; they are simultaneously attracted by the "old" monastic communities and exist in critical relation to them.

There are only a few studies concerning these communities (Hervieu-Léger 1986; Wittberg 1996; Landron 2004; Oviedo 2008) and they mainly focus on practical objectives, addressing such questions as: how should the ecclesiastical hierarchy behave towards NMCs, how bishops may recognise them canonically and how they can intervene to curtail certain eccentricities. This may result from the broader scarcity of sociological interest in monasticism and religious orders (Jonveaux et al. 2014; Jewdokimow 2018) which contrasts with historical and theological interest in the phenomenon of forms of consecrated life.

Studies show that NMCs are mainly concentrated in the United States and in Europe (predominantly in Italy, France and Spain) (Secondin 1991; Favale 2003; Rocca 2002, 2010), in the very regions where we notice a quantitative crisis of "old" forms of religious life. This reveals a general view that NMCs may be seen as a response to the crisis. These are, for instance, Bose (Italy), Figli di Dio (Italy), La Piccola Famiglia dell'Annunziata (Italy), Fraternitè monastique de Jerusalem (France), Fraternidad Maria Estrella de la Mañana (Spain), La Famiglia monastica di Betlemme, dell'Assunzione della Vergine Maria e di San Bruno (Italy), Ricostruttori nella preghiera (Italy) (Palmisano 2015, p. 14). ${ }^{3}$

2 It should be stressed that most NMCs are being recognised as (private or public) associations of the faithful and not as orders or institutions of consecrated life which results from the 1983 Canon Law regulations.

3 One shall also recall here Protestant and Ecumenical communities such as, for instance, Taizé, the Bruderhof, the Evangelical Sisterhood of Mary, Bonhoeffer's Finkewalde community in Germany, the Iona Community in Scotland, and the Community of Jesus in Cape Cod. All these communities have no relation to Vatican Council II, and as such, they do not meet our operational definition of NMCs (see in this article Section 1.1. Defining NMCs), and transcend the focus of our article which is Catholic monasticism. However, it also should be stressed that these communities have contributed to the phenomenon of the contemporary renewal of monasticism, and as such, should be recalled in the article on NMCs. It is an inspiring 
Stefania Palmisano counted 50 NCMs in France, in Italy 45, and in Spain 10. However, due to the short lifespan these numbers should be frequently updated.

It should be stressed that the novelty of the term 'new monastic community' may be simplified because some monastic orders, established before Vatican II, renewed themselves in accordance with the Council's decrees, hence, they have been adaptive and innovative (these are: Benedictines, Cistercians, Trappists, and Camaldolians). Also, some of the NMCs which emerged after Vatican II are traditional in their modus operandi, meaning that they have reintroduced anterior liturgical forms, customs and traditions (for example, La Famiglia monastica di Betlemme, dell'Assunzione della Vergine Maria e di San Bruno (Italy)). However, after Vatican II, innovations introduced by classical monastic orders into their centuries-old existence did not challenge the inherent assumptions of monasticism while NMCs refer to this tradition freely, and thereby, challenge it.

We will demonstrate how they renew monastic life by emphasising and radicalising the most innovative and disruptive theological aspects which they identify in Vatican Council II, inter alia, monks and nuns living in the same complex; they restrict enclosure and limit collective prayer time in order to increase time available for labour, for evangelisation and voluntary social work, often outside the monastery; they are actively involved in ecumenical and inter-religious dialogue, and harbour barely concealed sympathy with oriental religions.

We will focus on the selected community—-the Jerusalem Monastic Fraternity (JMF)—present its traits and discuss them in reference to the broader question of monasticism today. We focused on two communities established in Poland in 2010. We conducted interviews with five nuns and five brothers and performed participant observation during a lunch and recreational time in a female monastery. Interviews were transcribed and analysed in reference to research questions.

\section{Findings}

\subsection{The History of The Jerusalem Monastic Fraternity and in Poland}

In our study, we focused on two JMF monasteries located in Poland in the centre of Warsaw (they came to Poland in 2010, at the invitation of Cardinal Glemp). The two monasteries (male and female) are situated in one complex-from the street they appear to form one institution, but although the entrances and all other spaces are separate, they co-operate closely. In the male branch, there are 4 monks and, in the female, 11. There are three lay communities connected with the JMF in Warsaw: a community of families, an evangelical community and a community of Christian meditation. There is also a foundation (the Jerusalem Urbs Beata Foundation ${ }^{4}$ ), which is run by lay people. The foundation also manages a shop. ${ }^{5}$

The Jerusalem Monastic Fraternity was founded in 1975 in the Paris church of Saint-Gervais et Saint-Protais by a diocesan priest, Pierre-Marie Delfieux, with the support of the then Archbishop of Paris, Cardinal Marty. The desire to set-up a new kind of monasticism at the heart of the capital grew out of the young Delfieux's experience as a student chaplain at the Sorbonne during the years of contestation and matured while he was spending two years as a hermit in the Sahara Desert. Although interested in monastic life, he was critical of the form it had assumed over time, particularly medieval monasticism which he considered "rustic, cloistered and abbot-bound" and he agreed with Cardinal Marty that "Millennium monasteries" 6 should necessarily spring up within the walls of Paris.

Whereas the name "Jerusalem" appeared some time (1978) after the foundation-initially the community was called "Saint-Gervais"- the adjective "monastic" was present from the beginning

issue to investigate common points and differences of the contemporary process of returning to monasticism in different Christian denominations (for more on Protestant monasticism see for instance: Tennenhouse 2016; Eccles and Simon 2016; Montemaggi 2016).

4 See http://urbsbeata.pl/o-nas/.

5 See http://wspolnoty-jerozolimskie.pl.

6 This desire had already been expressed by Cardinal Marty during a 1972 Paris lecture (Cf. Marty 1979, pp. 43-47). 
even though Delfieux immediately recognised a problem of definition when he questioned whether or not they were monks. Recognizing that only the future could answer that question, the problem was agreeing upon what "monk" meant. Monks should try to find a new way of living the truth of the Beatitudes in their time. According to Delfieux, the plan for this new life form would not be pastoral, sacramental, pedagogic or charitable but contemplative. In 1979, Cardinal Marty himself gave a monastic frame to the new community, placing it—as soon as its statutes have been approved — under the patronage of a traditional monastery.

Delfieux's choice of an urban setting led to specific organisational decisions: that of rented accommodation; salaried employment outside a cloister which had by now become metaphorical; special attention towards the liturgy understood not only as opus Dei but also as a public service which, as such, should at the same time manage to be attractive and "nourishing" for its participants. There followed the choice of a liturgical form which joined together creative aspects of active participation and a preference for places with artistic and architectural value which became excellent backgrounds for carrying out liturgical rites. Monks and nuns are divided not only by Canon Law, but also into two distinct institutions. They are usually both present in their various communities, sharing not only liturgical prayer by singing together in polyphony, but also doctrinal education and festivities.

\subsection{Egalitarian Features-Mixitè}

One of the traits of NMCs is challenging the strict division of male and female realms. In the case of JMF in Poland, there are two distinct, male and female, monasteries living in a very close symbiosis which may be called mixitè. It is not so developed as in some other NMCs where nuns and brothers live under one roof (as in Bose). Mixitè is one of the egalitarian characteristics of the JMF. For JMF, it means sharing liturgy, doctrinal instruction, singing lessons and festivities; they cooperate on a daily basis, for instance, in terms of economy; but lodging, community governance and vocational discernment between monks and nuns are separate and independent; they also remain distinct institutions in the eyes of Canon Law. While developing the Constitution, Delfieux indicated a preference for a configuration, whereby the male and female branches were part of the same institute. Although this option was vetoed by the Congregations for Institutes of Consecrated Life, JMF monks and nuns perceive one another as complementary and as belonging to the same family. According to the founder, the Church-historical reasons which caused an almost absolute separation between men and women was not evangelical but rather historical-cultural and sociological. The decision to associate monks and nuns is interpreted as a return to its origins, ${ }^{7}$ taking on the value of exemplary witness.

Both nuns and monks from JMF understand this symbiosis in a broader context, as part of the critical process of changing the position of women within society—and with the reserve recognised by the Church-yet welcomed by the community.

"Surely this is a sign for the Church, because women, sisters, here are not subordinate but are quite autonomous. Sometimes because the community came from France, affirming its importance is necessary and I suppose that it has something of a feminist spirit, yet it is not feminism [ ... ] often in France when we meet sisters, I get the idea that these women are shaped by French society where a woman holds her head high and does not wish to let a man rule her [ ... ] So I suppose that this a sign not only for the world but also for the Church. I was very pleased when Pope Francis said a few years ago that a woman is not meant to be a servant. Also, the sisters have their own Superior, their training, their finances and are in no way subject to the brothers." (M2)

7 In this context, Delfieux quotes both passages from the Bible which testify that Jesus had a female entourage (Luke 8:1-2; 23, 69; 24, 10 and Mark 15:40-41) and examples of mixed monasteries in the past, such as Caesarea (fourth century) and Fontevrault (eleventh century). 
"When we pray together, when we are together, then there is a fullness, the beauty of creation is shown even more [...] Pierre-Marie [Delfieux] asked for a testimony of chastity in this unclean world, that one should live in pure friendship [...] I have called it my own way to be like brothers and sisters, but you also have to look after it. If we do not fulfil this, we do not know each other, then there is no such communion, being close enough to be as brothers and sisters, and apart enough to be as brothers and sisters." (S1)

Interviewee S1 said that their approach towards a woman in the world derives from "human dignity" and not "feminist theology". According to her, shaping these kinds of relationships between men and women is relevant for the Church too. If priests are afraid of women, then this fear might manifest itself as ill-treatment or humiliation. This is the result of poor formation in seminaries.

In order to "be like brothers and sisters", meaning establishing an egalitarian community, nuns do not confess to brothers with whom they live because it would make their relationship asymmetrical and mixes up roles. According to S1, this gender pattern is not typical of Polish monastic culture:

"I remember my meeting with enclosed sisters, probably Carmelite. They said, so you have brothers. I replied that we are brothers and sisters together. So, you have fathers, your fathers to look after you. I replied, no. They have Carmelite fathers who are nearby, and they speak out and watch over them, they confess to them. I said we are brothers and sisters, they are not our fathers, and we do not confess to them, we do not confess to our brothers in principle, unless it is strictly necessary."

Mixitè illustrates the intention to build symmetrical, democratic relationships in the everyday life of the community. Another example of this being everyday duties such as cleaning, these jobs are shared equally in order to avoid overloading any one individual.

\subsection{Openness Towards the World}

Another trait of the JMF is openness towards the world. Of course, it is not specific for either Catholic religious orders or for monastic orders since Benedictines or Cistercians also engage in "in-the-world" activities. However, the JMF elaborated upon this connection innovatively. For the JMF, being open to the world is a multi-directional endeavour-it may be found in their relationship towards the city, work and in the structure of daily rhythms.

\section{The Osmosis with the Contemporary Desert}

Brothers and nuns repeat that the aim of their vocation is: "Being in osmosis with the contemporary world (here meaning the city), being accessible, and being a sign of God". According to interviewee M2, the Jerusalem Community aims at "liv[ing] in osmosis with the world, we are not separated from it by any enclosure". However, they direct themselves to the monastic tradition and to active forms of the religious life. Osmosis with the city takes place on many levels: living and working within it, and understanding themselves as individuals brought up in that city:

"The city looks in from every side, now there is silence, but [when] something is going on outside, or there is a demonstration in the street, something is happening. And it is our task to be monks in such a world, without abandoning it [ ... ], the founder [claimed], we could theoretically be closed and separate from the world, but we have a form of life to share, being holy, living in harmony with God and at the same time seeking the deep connection with God which takes place in the heart thanks to silence and self-discipline." (M2)

Osmosis with the city is not only being practised by monks, but it is also embedded in the fabric of their monasteries. In Poland, the monastery is located in the city centre, next to a soccer stadium and on a very busy route. Noise is clearly audible in the monastery: 
"We have a place, in Cologne, which is located in the tourist district and where there is a lot of activity, carnivals, and so forth. And the refectory, for example, where the reading room is with many windows, and in the evening it's just brothers in a goldfish bowl: people are walking down the street, and you can simply look inside. ${ }^{8}$ It is the same in Paris, the same way where you come to the kitchen to cook dinner and the window is in the yard, and the courtyard is surrounded by a multi-storey tenement buildings, we are visible from the 10th floor. And this is a conscious choice, to be among people [ ... ] In any case, the choice of this life, being accessible, its source is solidarity with them [people living in the city] and the desire to be close to them, to be available and to feel compassion for them." (M2)

Being centrally located means that the monks may be easily "accessible" and hence, they indicate the presence of God:

"So it seems to me that what is relevant about us is the fact that we do nothing, we do not give anything concrete, we do not produce anything, often we do not speak, but we choose life in the presence of God because He is so important to us [...] In fact, in such a large, modern city it is a difficult experience to come into contact with such an environment in which it is difficult to experience the spirit and go deeper." (M2)

The concept of the city is central to the theology of the Jerusalem Community. Of course, they are not the first religious order to locate its work in the city. From the 12th and 13th centuries onwards, monasteries were founded in the largest European cities by the Franciscans and Dominicans. Monasteries of different monastic orders have also been situated in cities, for example, the female Benedictines, Salesian Sisters or female Carmelites (Carmel), to mention but a few. According to M1, what distinguishes previous monks from the "new" ones is their attitude towards the city which they perceive as something not to be opposed, but within which one has to integrate. ${ }^{9}$ For them, the city is the new desert where one may sacralise himself/herself. According to interviewee S1:

"Our unique attraction is actually life in big cities. This is an important element of our spirituality, big cities that are deserts, spiritual deserts. It has such a double positive and negative dimension in the sense that monks in the first centuries went to the desert, they searched for a place of loneliness, to seek God, to struggle with sin, to fight the devil, so here is our aspect of searching, the purification of the heart, our aim to be closer to God. The aspect of the desert as a place that does not give life, as a place without God [ ... ]. So, this is the reality of the city, where a human created for communion, for love, for living in a brotherhood and for friendship, dies from loneliness." (S1)

Interviewee M1 highlights:

"The city is a spiritual desert because of the fact that the major stimuli in the city are work, play and entertainment. The spiritual dimension is weak here. And people leave the city and go towards nature, or perhaps into monasteries, right?" (M1)

According to S1, part-time work as a feature of the JFM should be reconsidered because it may be outdated being more attuned to the industrial era. The most recent general assembly of the JFM agreed that they have to look for new ways of demonstrating solidarity within the city. The interviewee S1 also claims that the practice of dividing time between working outside and living the life of a community of prayer inside is challenging and should be reconsidered because it is not easy to combine both in the present day.

8 For further information see: http://wspolnoty-jerozolimskie.pl. A brother to whom I talked (from the Cologne community) told me they do not feel as if they are being watched. See http://jerusalem.cef.fr/cologne-gross-sankt-martin/6310-gott-ist-inder-stadt, a video created by monks and sisters from Cologne describing their life in the city.

9 However, one may recall here the urban monasticism from the fourth and fifth centuries. 
The interviewee M1 underlines that the contemporary city is entirely different from the city of the 1960s and 1970s, and, therefore, one needs to find a way to connect with this new reality.

Then, [1960s/1970s] the reflection could have been really more direct, solidarity with those who go to work, live in rented flats and are city dwellers. Brothers doing part-time work [... ] showed solidarity with the city and it was possible and greatly emphasised because everyone worked eight hours from 8:00 or from 7:00 to 15:00, normal working hours, so the brothers followed this pattern, but it has changed a lot. Today, the world of work and the world of the city have changed very much, and in this respect, we are looking for a new way to show solidarity with today's city." (M1)

\subsection{Monks as Citizens and Workers}

The specific spatial collocation of communities in the urban context is related to their other choices: of being not owners of property but renters, as well as the fact that monks and nuns tend to have an ordinary job outside the walls to which they are bound, as other workers all contribute to defining the identity of monks in the cities. The brothers and sisters work part-time to demonstrate their solidarity with lay people but also to combine contemplative and active elements of their life. However, work is less important than prayer and communal life.

Their work sense emerges from interviews with nuns: paying rent (where necessary), running accounts and setting aside a part for the poor, as well as sharing the fatigues of men and women working in the world. They tell us that part-time employment in communities can vary: some translate; others sell sacred objects, arts and crafts, cosmetics, honey, jams and marmalade in the monastery shop; some make icons; others are church secretaries. Nuns who are not so busy or who are studying deal with shopping, cooking and other domestic chores, such as being bursars. Such work should conform to the founder's criteria in the Fraternity Rule. Quoting Saint Basil, he points out: "This general rule may be established: choose the activities which safeguard our life in peace and tranquillity, which are not technically very difficult and do not lead to dangerous or unsuitable meetings" (Delfieux 2005, p. 36). ${ }^{10}$

There are four brothers in Warsaw and one novice (there are around 60 brothers worldwide). Now, only one brother works outside the monastery (in a Catholic institution), while others work within the monastery (three focus on church services and one-a hermit-as a translator). The sisters work in different professions but only in Catholic institutions. In the words of one of them:

"We work in various occupations according to what work can be found. Sometimes according to our studies, but we do not necessarily look in this direction, we have so many limitations, so if we can find any job, we are happy. We need to work only part-time and we cannot work on Mondays, because we have 'desert' days. And this form of work is becoming less and less popular." (S1)

The tension between contemplative and active elements is mirrored in the daily rhythm. A day is divided into two parts: the first part being work and active time; the second, communal, meditative time. On Monday, there is a day of the "desert" (no work and no communal praying). From interviews with the nuns, it further emerges that one of the severest difficulties of their monastic life-which they interpret as the most fatiguing form of ascesis-is the rhythm, the rigid timetable structure "fragmenting" their days and governing not only opus Dei but also their other daily activities (to avoid wasting time), giving them the sense of always being interrupted.

"You go to work, you come back, you have the rhythm of prayer, you have to do this, you have to do that ... How to manage it all? When you are young, you do not care about your health and you do too much which is against yourself ... " (S1)

10 Translation of all quotations of Delfieux 2005 from Italian by Stefania Palmisano. 
Another nun claims that because of this difficult composition of daily life a nun has to be mature to handle it:

"So, if you want to combine these two areas, you have to be mature, then you will be able to do something outside in this Jerusalem which is the city, to work in the city, and then be able to come back and live here, inside." (S2)

The nuns also testify that while one gets used to this daily cadence, it is still a central aspect of their lives which they have to take into account: even if they are talking to somebody or reading, they have to stop and obey the call. Then there are other activities connected with daily life which intrude the nuns' lives, sometimes during prayer, lectio divina, or work (for example, when supplies do not arrive on time). In addition, nuns who are required to meet and talk to somebody may arrive late to the chapel for (individual) prayer, but they try to be punctual for the liturgy. They are not reprimanded by superiors if this happens infrequently, but this kind of "bother", i.e., "being disturbed by the world to the extent of finding oneself of the world", is a consequence of choosing to live in the city rather than retiring to the country. This last quotation comes from a monk whose order has monasteries in two European cities which are partly built of glass so that people can see them and acknowledge their existence. On Wednesday evenings after Chapter (an assembly of the whole community with males and females separated), ten minutes are devoted to "self-confession" where, after a hymn to the Holy Ghost, everybody (male and female) is free to talk about his/her omissions (e.g., being late, breakages, uncharitable thoughts and forgetfulness) and to ask for the community's forgiveness.

Living within the city is balanced with contemplative and communal (religious community) practices combined with prayer. This does not mean exclusion of people or seclusion from the world. In the JMF there is no papal enclosure. Monks and sisters work outside the monastery, which is also a challenge for them:

"Our founder said that our monastery is a city. It does not mean that we go where we want, we do what we want. When we leave the monastery, we talk about it, we ask for permission. It is clear that I will not ask for permission to go to work, but if I have a certain path, I stick to it and I will not jump to the right, to the left, or take advantage of the fact that I went to work and I will do it, I will not walk around half of the city without telling anyone. Our lives require a lot of maturity, that you have to demand from yourself, to know why you came here. You can probably say that about every monastery, but the enclosure protects you." (S1)

\subsection{Enclosure and Fuga Mundi}

The traditional value of enclosure has been lost in the JMF. Although it does not appear, its meaning is radically transformed through a process of metaphorisation: from "mural" to "moral", i.e., from a place of radical separation from the world, a tangible expression of fuga mundi (flight from the world), a tool which permits safeguarding the self and contact with God. Even when the enclosure is partly mural, it becomes less a matter of space and more of time-management. The Constitution of the JMF states: "The monks/nuns adopt the reality of effective enclosure by living in a house reserved exclusively for them, particularly safeguarding the inviolability of their cells, every day ensuring periods of complete silence and perfect solitude and every week an entire 'desert' day in favour of a heart-to-heart with God alone." The Jerusalem Monastic Fraternity members consider traditional monastic enclosure as a means adopted in the past for reasons of historical-cultural contingencies. On this point, Delfieux writes: "Do not worry about that which is difficult to base explicitly on the text of the Gospels" (Delfieux 2005, p. 127).

\subsection{Openness Towards Extra-Catholic Traditions}

The last feature to be discussed is openness towards extra-Catholic traditions. The community is Catholic, with no members from other Christian denominations. Some Anglicans and Eastern Orthodox who were interested in the community converted to Catholicism in order to join it. The community's 
male and female branches are recognised today as institutes of consecrated life, which means that they must be Catholic. They take vows publicly in the Church. The intention for the future is to establish a federation of institutes, both male and the female, following the pattern of other communities (see the canonical recognition of the Beatitudes monastic community). Eastern influence, rather than Protestant, can be seen in the liturgy. The Catholic charismatic movement was stronger at the beginning because Delfieux's first spiritual brother came from that background, and still today, some brothers and sisters in certain communities share charismatic forms of prayer-but it is not present in Poland. The Warsaw community, however, offers hospitality to a charismatic prayer group which gathers in the chapel once a week.

The Jerusalem Monastic Fraternity combines broad social legitimation with canonical recognition as an institute of diocesan law. They came to this point step by step. The first stage was the elaboration of their statutes in 1979, consequently raised to a Pious Union. Later, after its recognition as an Association of the Faithful in 1984, both Constitutions ad experimentum were approved (the male branch in 1991 and the female in 1992) and finally the founding of the two Religious Institutes in 1996.

Having been recognised as two distinct institutes of consecrated life, both male and female communities are now working towards recognition as a federation.

\subsection{Liturgy}

The liturgy, like the Rule, is "composite": combined with elements drawn from the Western monastic tradition (reading the divine office and lectio divina) are new ones deriving from other Christian traditions in such a way that novices do not understand them fully. The liturgy is limited to three points during the day (Lauds in the morning, Sext at midday and Vespers before Mass in the evening) in order to allow the monks to work outside the community. Both monks and nuns attend these celebrations, singing in polyphony; they are separated before the presbytery but not distant from one another-they do not sit in stalls, but instead face the altar like the faithful.

One of the most noticeable aspects is the presence of Byzantine elements: icons, crosses, hymns, the daily incense ritual; the practice of metonymy, ${ }^{11}$ lighting up the dome, icons, the altar and the menorah (the Jewish candelabra) with candles. Further characteristics are the use of various musical instruments at times which are usually dedicated to silence and more use of the body, originally inspired by Charismatic Catholicism by adopting different positions during prayer (mostly on foot, sometimes with arms raised and other times sitting on their heels) or movements (frequent processions, bowing, metonymy, interacting with the faithful).

According to interviewee M2, people today are developing a need for contemplative Christianity, related to prayer, silence and Eastern orthodox spirituality. It attracts not only young people, but also consecrated people.

"This need for another Christianity, as well as the different religious life that it expresses, among other things, not only that people can go there, young people, but that new communities, in any case Jerusalem, attract people who are already in the consecrated life and who come here from other communities or diocesan priests. There is also a characteristic feature that among us there are many who have a past in other forms of consecrated life, there is some difference and there is some novelty for which there is a demand, the model is not universal, it is not mass, but it is real. Also, there are among us former Benedictines, priests and sisters...as in France. The first group among Jerusalem communities, which was established in the 1970s, was composed of formers monks." (M2)

11 Touching the ground by hand and then making the sign of the cross, repeating the sequence three times while singing a litany. 


\section{Discussion}

Most NMCs were established after Vatican II and they are strictly related to the spirit of the Council: they have egalitarian characteristics (specifically male/female relationships and lay and religious people), openness towards extra-Catholic traditions and to the world. This results in many organisational innovations in comparison to classical monasticism such as: mixed male-female communal life and increase in status of women or broader individual autonomy. We recognised these aspects in the JMF under study. Sociologically speaking, NMCs represent many traits of advanced modernity such as: individualisation, gender sensitivity and self-fulfilment, to mention but a few. Modern, reflexive societies are strictly attached to the city. Monasticism emerged in the deserts, yet the version re-elaborated by the JMF has recognised this hyper-modern locus as the contemporary desert, and by doing so, aims to be present here in the same way as first monks were in their locations.

The JMF not only follows Vatican II principles, but it also adapts to the changing social environment in which they operate. They have understood the nature of contemporary work and aim to transform their working practices accordingly. We claim that the JMF are not only new, but they are also adaptable and attentive towards the contemporary world. By doing so they also re-connect with that world, treating it not as a threat but as a challenge and a natural environment.

Following social changes and actively looking to understand what the world requires from them, the community under study also seeks to adapt to the Polish context:

"This is a great joy for me, being among people who do not want to be separated, but who want to be open, to listen and to be what the world needs today [... ] We are not seeking to establish long-term forms but we are trying to listen and to understand what the world needs today and what we can do." (M2)

According to S1, all communities from the JMF have changed in their daily practices within the timespan of their existence. For example, sisters must have mobile phones with them while travelling by car in case of accident:

"Our rules are to serve life, and they are not to make us rigid or anachronistic." (S1)

Another adaptation is related to domestic tasks:

"To give an example, in France sisters do their own washing, but here there is no space, the laundry is in a tiny place, and there is nowhere to hang washing, so it is tumble-dried in a machine. For as long as I can remember, sheets were hung outside to dry. It has become more and more expensive; they are asking us to bring sheets to a monastery. I am preparing myself here and saying-we will be doing the washing ourselves-and then the General, she says 'No, not like in Paris', for her it was unthinkable that we would add further duties. I say, but who will pay for it? In our culture, it is a luxury and only hotels would do that, not sisters. Of course, we did not give it out anywhere, because she did not return to the subject. But during these last ten years she had not considered the issue from the Polish perspective."

Apart from practical, organisational differences, NMCs also differ from the ordo monasticum in terms of identity. They consider classical monastic orders to be outdated and believe that their means of differentiating themselves from the older orders convey a sense of the authenticity of their religious-life choices. New Monastic Communities remain in profound relationship to them-they purposefully choose elements from traditional monasticism which they reshuffle like bricolage.

Comparing old and New Monastic Communities is a promising field of study revealing various dynamics of tradition and adaptations to present social evolutions. Monastic life in Europe is not homogeneous, especially not in its relations with society, the institutional Church and the history of monasticism. New communities founded after the Council adopt a position of fracture from tradition, whereas old communities consider it as a pillar of their identity and their justification for existence. But joint evolutions of the new and the old are reducing the practical differences between them. 
Variegated patterns can, therefore, be observed, constituting an unstable set which is open to evaluation according to external criteria. It would be interesting to explore the factors accounting for why new communities flourish in some societies (for example, Italy and France), and not in others (Austria), which welcomes new communities founded in other countries. Founding new communities is closely linked to a country's religious circumstances and older communities' contemporary position.

\section{Conclusions}

The NMCs seek to position themselves as a (re)invention of tradition, which is thought to mean a radical break with traditional monasticism. But the difference between new and old communities is not only a matter of degree: thus, this hiatus is barely noticeable if we simply compare the daily-life practices of the two, in efforts to find the instigators of the boldest changes. This attempt is destined to fail because traditional communities are today much closer, in practice, if not in theory, to the new communities than either of them would be willing to admit.

Moving on from the analysis above we shall now tackle the main question of this article: are NMCs (especially JMF) a response to challenges which monasticism faces today? In order to answer this question, it is worth pointing out that new and traditional monastic communities are not so very different as might appear at first. Three main reasons explain their tendential similarities:

1. In the wake of the Second Vatican Council, traditional monasteries changed profoundly in order to adapt to modernity, introducing important innovations which followed, in a similar vein, the orientations of the NMCs, thus reducing the practical differences between both of them. Monasticism - as we by now clearly understand - is not exempt from transformations assailing society as a whole. It is, therefore, no surprise that the individualistic impulses of advanced modernity have not stopped at the monastery gates.

2. Particular NMC innovations have proved to be the founding precepts of traditional communities outside Italy. While it is true that radical changes have been introduced by the Italian NMCs, those changes have been only tenuously adopted by most traditional Italian monasteries, yet traditional communities can be found in Europe where the style of life closely resembles that of the NMCs. Examination of contemporary European monasticism reveals marked differences in the organisation of community life, mainly explained by the variable of each individual country's social and religious history. To give but one example, abandoning enclosure in favour of work outside the monastery is considered typical of NMCs, and one of their primary innovations. But a study of traditional monasteries in Austria demonstrates that most of their work takes place outside the monastery, in schools or in parishes. ${ }^{12}$ External work, far from being a novelty, has its roots in the eighteenth century when Emperor Joseph II, in line with the theories of the French economist Quesnay, promulgated a law closing religious communities which did not benefit society.

3. The largest and most prosperous NMCs are facing a process of institutional integration and operational routinisation which has the effect of eroding the innovative elements characteristic of their original flowering. As a consequence, they have ended up resembling traditional communities. The history of Bose is an example of this process. This community, born out of a radical return to the origins of monastic life (austerity, poverty, small in size, work outside the monastery, no habit, sober liturgy), experienced rapid social and economic development leading it gradually to abandon its original form for the traditional monastic model (buildings of monumental stature, work within the monastery, liturgical habit, polyphonic and, sometimes, Gregorian psalmody).

12 (Jonveaux 2014, pp. 71-86). 
Despite these similarities, we argue that NMCs are, in reality, a response to challenges threatening monasticism today. Being aware of a vocational crisis, the community adapts to the contemporary world in many innovative respects. It does not negate the contemporary world, but instead seeks to understand it and follow it not only in its organisation but also in attitudes towards individuals.

This form of community is attractive to different groups. In terms of vocation, approximately 40 women have applied so far to join the female monastery (in the male section only three). Ten were accepted into the novitiate but only two took their final vows. Most of the applications were refused due to age (most of the applicants were over 35 years old, some over 45), and problems related to it, mostly with adapting to the cultural conditions in a monastery which expects subordination.

In 2017, the JMF performed a survey and distributed questionnaires to people attending Mass. Eighty respondents, lay people, declared that they came here, in the first place, because of the silence, the atmosphere of the church, the liturgy and worship. Consecrated people also participate in their liturgy and seminars attract people from Warsaw and beyond who "seek silence" and "humility" (M1).

To conclude, it is important to highlight that there is no sharp distinction between traditional and New Monasticism, with the first being static and obsolete, and the second active, in tune with transformation within the social context. We are witnessing an intersecting movement: while old communities are changing to become more like the new, the latter are becoming institutionalised and assuming the structure and patterns of the former. Well then, in the light of this tendential convergence, how can we explain the difference between them? The proposed answer in this paper has been that it is not a matter of degree but of changing perspectives. Goffman's metaphor of "frame" as "definition of the situation" helps to make this point clear (Goffman 1974). Working within a framework implies taking for granted (or at least sharing) the assumptions, rules and values of a given interaction context. Modifying the frame means calling it into question, problematising it or changing it. Monastic tradition may be interpreted as a frame to the extent that it institutes common sense with regard to how a monk's or a nun's life may be put into practice; a re-working intended to judge or modify its basic assumptions means changing the frame. Consequently, we argue that: (1) some NMCs are more similar to traditional monasticism than others and (2) "old" monasticism has also changed and attempted to keep up with modernity. Hochschild (2013) investigated interpretative variations based on a comparative study carried out in eight Benedictine monasteries in Germany, Austria and Hungary, developing the concept of "elastic tradition". According to these authors, the most evident differences among these monasteries are not only due to the leadership, constitutions and rules but also to the national differences regarding the role of the Catholic Church in the public sphere and in the theological debate as well as the novices and postulants' socio-cultural background.

Despite these similarities, we maintain that NMCs have triggered a paradigm shift which is particularly in tune with contemporary spiritual and religious research, which claim is supported by two research findings:

1. New Monastic Communities were born outside the Ordo monasticus. Whereas traditional communities introduce innovations which do not, however, invalidate monasticism's basic assumptions (which remain in the frame), NMCs question these assumptions (in which sense they are changing the frame) and they redefine the very identity of monasticism. Let us give some examples. No matter how hard Benedictine communities try to update the Regula Benedicti, they cannot abandon it; on the contrary, their loyalty is ensured by almost daily reading of a chapter. No matter how much they encourage collaboration between monks and nuns in neighbouring monasteries, they have no interest in initiating experiments of cohabitation "under the same roof". Ultimately, Benedictine monks wish to preserve tradition because they see in it the source of legitimacy of monasticism itself. Therefore, to integrate the changes which they make, they develop strategies of recomposition (for instance, as Jonveaux notes, they invent religious-type justification for professional and economic innovations). In any case, the changes-often imposed by the necessity of adapting to transformations of society or market imperatives-are registered in monasticism's chain of memories. Briefly, the principal divergence between old and new communities is their ideological position vis-à-vis tradition, which 
marks a watershed: in old monasticism, the institution is the guarantor of tradition, instilling respect for its basic assumptions, whereas in New Monasticism, founders interpret tradition liberally, developing it creatively by modifying its basic assumptions.

2. The discomfort of ecclesiastical authorities tasked with validating NMCs' authenticity confirms the gap between old and New Monasticism. Bishops are reluctant to legitimise them because they subvert the traditional requisites of religious life; in other words, they "change the frame". Apart from the problems that bishops have to face in managing their dioceses, the mountain of work under which they are buried and the lack of directives with respect to new communities, it is the audacity and disruption of NMCs' innovations (mixité, ecumenism, temporary vows) which slow down and delay the recognition procedure. In essence, it is the variable principle determining their ambiguous legitimacy which is the radical novelty of NMCs.

Author Contributions: Conceptualization, S.P. and M.J.; Methodology, S.P. and M.J.; Investigation, S.P. and M.J.; Writing-Original Draft Preparation, S.P. and M.J.; Writing-Review \& Editing, S.P. and M.J.

Funding: The article was financed with the resources from the National Science Centre (Poland), decision number: UMO-2016/21/B/HS6/01057.

Conflicts of Interest: The authors declare no conflict of interest.

\section{References}

Congregation for Institutes of Consecrated Life. 2017. New Wine in New Wineskins. The Consecrated Life from the Second Vatican Council and Its Ongoing Challenges since Vatican II. Guidelines. Rome: Libreria Editrice Vaticana.

Delfieux, Pierre-Marie. 2005. Come monastero la città. Un nuovo volto del monachesimo. Milano: Ancora.

Derwich, Marek. 2012. The main assumptions of the project Cultural heritage of dissolved monasteries on the territory of former Poland and in Silesia in 18th and 19th c.: Fate, significance, cataloguing. Hereditas Monasteriorum 1: 363-68.

Dilanni, Albert. 1993. Religious Vocations: A New Sign of the Times. Review for Religious 52: 745-63.

Ebaugh, Helen Rose Fuchs. 1977. Out of the Cloister: A Study of Organizational Dilemmas. Austin: University of Texas Press.

Ebaugh, Helen Rose Fuchs. 1993. Women in the Vanishing Cloister: Organizational Decline in Catholic Religious Orders in the United States. New Brunswick: Rutgers University Press.

Ebaugh, Helen Rose Fuchs, Jon Lorence, and Janet Saltzman Chafetz. 1996. The Growth and Decline of the Population of Catholic Nuns Cross-Nationally, 1960-1990: A Case of Secularization as Social Structural Change. Journal for the Scientific Study of Religion 35: 171-83. [CrossRef]

Eccles, Janet, and David Simon. 2016. The Community of the Resurrection: A Case Study in the (Re)Emergence/Evolution of Anglican/English Monasticism. In Monasticism in Modern Times. Edited by Isabelle Jonveaux and Stefania Palmisano. New York: Routledge, pp. 173-90.

Favale, Agostino. 2003. Comunità nuove nella chiesa. Padua: EDB.

Finke, Roger. 1997. An Orderly Return to Tradition: Explaining Membership Recruitment to Catholic Religious Orders. Journal of the Scientific Study of Religion 36: 218-30. [CrossRef]

Finke, Roger, and Rodney Stark. 1992. The Churching of America, 1776-1990: Winners and Losers in our Religious Economy. New Brunswick: Rutgers University Press.

Finke, Roger, and Rodney Stark. 2000. Catholic Religious Vocations: Decline and Revival. Review of Religious Research 42: 125-45.

Finke, Roger, and Patricia Wittberg. 2000. Organizational Revival From Within: Explaining Revivalism and Reform in the Roman Catholic Church. Journal for the Scientific Study of Religion 39: 154-70. [CrossRef]

Goffman, Erving. 1974. Frame Analysis: An Essay on the Organization of Experience. Cambridge: Harvard University Press. Greeley, Andrew M. 1972. The Catholic Priest in the United States: Sociological Investigations. Washington: United States Catholic Conference.

Hervieu-Léger, Danièle. 1986. Vers un nouveau christianisme? Introduction à la sociologie du christianisme occidental. Paris: Éditions du Cerf.

Hochschild, Michael. 2013. Benediktiner zwischen Kontinuität und Wandel. ... einem internationalen Forschungsprojekt. Erbe und Auftrag 1: 23-45. 
Hostie, Raymond. 1983. The Life and Death of Religious Orders. Washington: Center for Applied Research in the Apostolate.

Jewdokimow, Marcin. 2018. Klasztor w perspektywie socjologicznej: W poszukiwaniu nowego ujęcia [A Monastery in a Sociological Perspective: Seeking for a New Approach]. Warsaw: Wydawnictwo Naukowe UKSW.

Jonveaux, Isabelle. 2014. Redefinition of the Role of Monks in Modern Society: Economy as Monastic Opportunity. In Sociology and Monasticism: Between Innovation and Tradition. Edited by Isabelle Jonveaux, Enzo Pace and Stefania Palmisano. Leiden and Boston: Brill, pp. 71-86.

Jonveaux, Isabelle, Enzo Pace, and Stefania Palmisano, eds. 2014. Sociology of Monasticism: Between Innovation and Tradition. Annual Review of the Sociology of Religion Series No. 5. Leiden and Boston: Brill.

Landron, Olivier. 2004. Les communautés nouvelles. Nouveaux visages du catholicisme français. Paris: Éditions du Cerf. Marty, François. 1979. L'eveque dans la ville. Paris: Éditions du Cerf, pp. 43-47.

Montemaggi, Francesca. 2016. The Making of the Relational Christian Self of New Monastics in the UK, US, and Canada. Edited by Isabelle Jonveaux and Stefania Palmisano. New York: Routledge, pp. 209-28.

Oviedo, Lluís T. 2008. Should we say that the Second Vatican Council has failed? The Heythrop Journal XLIX: 716-30.

Palmisano, Stefania. 2015. Exploring New Monastic Communities. The Re-Invention of Tradition. Aldershot: Ashgate. Rocca, Giancarlo. 2002. Nuove forme di vita consacrata. Vita Consacrata 38: 563-75.

Rocca, Giancarlo. 2010. Primo censimento delle nuove comunità. Rome: Urbaniana University Press.

Sammon, Seán D. 2001. By Their Fruits You Shall Know Them: The Challenge of Renewal Among Men Religious in the USA Today. Social Compass 48: 209-28. [CrossRef]

Secondin, Bruno. 1991. I nuovi protagonisti. Milan: Paoline.

Tennenhouse, Laura F. 2016. New Monasticism as 'Reflexive Spirituality': A Case Study of the Simple Way. In Monasticism in Modern Times. Edited by Isabelle Jonveaux and Stefania Palmisano. New York: Routledge, pp. 154-72.

Wittberg, Patricia. 1994. The Rise and Decline of Catholic Religious Orders. Albany: State University of New York Press. Wittberg, Patricia. 1996. Pathways to Re-creating Religious Communities. Costa Mesa: Paulist Press.

(C) 2019 by the authors. Licensee MDPI, Basel, Switzerland. This article is an open access article distributed under the terms and conditions of the Creative Commons Attribution (CC BY) license (http://creativecommons.org/licenses/by/4.0/). 